\title{
Commercial English Language Proficiency: A Case of Exit Level Commercial Major Subject Students in the School of Education at the University of Limpopo, South Africa
}

\author{
Maruma* Mamalatswa Kgetja \\ University of Limpopo, School of Education, Private Bag X1106 Sovenga 0727 \\ Email: *kgetja.maruma@ul.ac.za
}

Modiba N. Solomon

University of Limpopo, School of Education, Private Bag X1106 Sovenga 0727

Email: Solomon.modiba@ul.ac.za

Gwaidepi Caleb

University of Limpopo, School of Education, Private Bag X1106 Sovenga 0727

Email: Gwaindepi@gmail.com

Musara Mazanai

University of Limpopo, School of Education, Private Bag X1106 Sovenga 0727

Email: jilram@yahoo.com

\section{Doi:10.5901/mjss.2014.v5n14p386}

\section{Abstract}

This article presents the findings of a study that was conducted to assess the commercial English language proficiency of Bachelor of Education (BED) 4th and Post Graduate Certificate in Education (PGCE) students majoring in Accounting, Business Management and Economics (commercial subjects) at Limpopo University. A proficiency test consisting of items testing commercial language expression, comprehension, and vocabulary and error correction in both written and oral conversations was administered to a sample of 106 students consisting of BED fourth (4th) year and PGCE students majoring in commercial subjects. The test was developed by acclimatising existing English Language proficiency test as well as by using items identified from existing literature. The reliability of the proficiency test was tested using the Cronbach's alpha coefficient. The results of the study revealed that although PGCE students on average scored higher in the proficiency test, their level of commercial language proficiency was below acceptable minimum. Furthermore, statistically significant correlations were found between general commercial English expression and Comprehension, between comprehension and Vocabulary as well as between Error correction and Vocabulary. These findings suggest that both PGCE and BED students require intensive commercial language teaching. Furthermore, actions to improve the level of commercial language proficiency of both groups are recommended.

Keywords: commercial English language, proficiency, exit level, South Africa

\section{Introduction and Background}

The South African schooling system, including higher education, is not set up for the successful communication in the world of work as well as for commercial English proficiency and this can no longer be taken lightly (Hove, 2012; Posel and Casale, 2011). Several scholars (Cumming,2008; Brock-Utne and Holmarsdottir, 2004; Rrobyn 2002; Heugh, 2000) remark that classes at both tertiary and basic schooling institutions are conducted in a combination of an African language (mother tongue) and English, although final assessments are solely done in English. These discrepancies have huge negative implications on the students' level of performance (Dang and Webb, 2014), given the mismatch between teaching and assessment practices. This further hinders proficiency in subject specific terminology since some terms cannot be easily translated directly from mother tongue to English.

There has been evidence provided in literature that the level of English language proficiency among the majority of South Africans leaves a lot to be desired. For example, Possel and Zeller (2010) in their review of literature observed that 
most studies conducted in South Africa found low levels English language proficiency among mainly black participants. The same sentiments are echoed in Hove (2012) as well as Webb and Kembo-Sure (2000). This begs the question why there are such low levels of English language proficiency among black students. Another concern raised in literature (Pradhan, 2013; Christie and Macken-Horrarik, 2007) relates to proficiency in the discipline specific language terminology among the students as well as the educators themselves. Educators are expected to be proficient in the discipline specific language in order to be efficient in their delivery and to inculcate the skill in learners. This is a major concern if one considers the importance of accurate and efficient communication in teaching and learning (Helmer, 2013) as well as in the corporate world, hence the importance of mastery of commercial English. Consequently, this study is an assessment of the levels of commercial English proficiency among BED $4^{\text {th }}$ year and PGCE students, with the aim of identifying the causes of low levels in commercial English proficiency in teaching and learning.

Acknowledging that existing studies investigated the general English proficiency, like that of Posel and Casale (2011) amongst others, the researchers deemed it fit to focus on commercial English proficiency among 4th year level and PGCE student teachers of Limpopo University. This was precipitated by the researchers' practical engagement with such student teachers, who demonstrated their conspicuous incompetency in comprehending and applying commercial language terminology in their daily interactions.

Assessment of commercial English proficiency could lead to the provision of suggestions on how to improve commercial language proficiency. In the context of this study, commercial English proficiency refers to the self-reported ability to read, speak and write commercial English (Casale and Posel, 2011). This study is therefore an assessment of commercial English proficiency amongst the Bed $4^{\text {th }}$ year and PGCE student teachers. Such an assessment was necessitated by the study's research problem about the low level of commercial English proficiency by the two categories of Limpopo University students.

The study aims to contribute to the endeavours to create opportunities to improve teaching and learning in commercial subjects in South African schools through assessing commercial English proficiency among exit level student teachers. To achieve this aim the following objectives were formulated:

- To assess the level of commercial English proficiency among B ED $4^{\text {th }}$ year level and PGCE students teachers at Limpopo University.

- To investigate whether there are significant differences between the commercial language proficiency of B ED $4^{\text {th }}$ year and PGCE commerce student teachers.

- To investigate the cause of low level of commercial English proficiency among B ED $4^{\text {th }}$ level and PGCE students teachers at Limpopo University.

- To provide suggestions on improving commercial English proficiency among B ED $4^{\text {th }}$ year level and PGCE student teachers at Limpopo University.

\section{The Rationale of Commercial Language Proficiency Assessments}

Generally, there has been relatively little research addressing level of commercial English proficiency of student teachers in their teaching and learning in South Africa. A plethora of literature reviewed, point out that, studies on the English proficiency in general has been undertaken. For instance, studies conducted by MacDonald (1990) as well as Webb and Kembo-Sure (2000) reveal that black students are disadvantaged because of lack of English proficiency. This lack affects even those in institutions of higher learning. Alexander (1995), Luckett (1995) as well as Heugh (2000) also argued that a failure to be proficient in English by speakers of African languages accounts for their poor performance in tertiary institutions. This is supported by Barkhuizen and Gough (1996) who contend that learning in English where proficiency is missing has always been problematic for countless students who are non-native speakers of English. Van Der Walt, Evans and Kilfoil (2009) also point out that English is the "linking language" used for a wider communication. However, its second language speakers lack proficiency in it. In this study, the researchers endorse the views of Probyn (2006) who argues that effective learning may not take place in a language in which students do not have appropriate language mastery.

Christie and Macken-Horrarik (2007) advise that commercial English students have to go beyond basic skills in order to integrate issues of personal growth and functional competencies in their learning of commercial language terminology. The argument for the need to grasp subject specific language is also well presented in Valipouria and Nassajib (2013) where differences in terminology application across disciplines are clearly documented. Alexander (2000) also argued that unless a student has a command of commercial English proficiency, he is eliminated from the competition for jobs and certain positions of status and power. This suggests that being proficient in commercial English 
has benefits. Nico (2004), Alexander (2003), Finlayson (2002), Heugh (2000) as well as Nkabinde, (1997) conclude that the benefit of being proficient in commercial English lies in better chances to succeed in the competition for economic goods and status. Furthermore, Helmer (2013) emphasizes the role of subject specific language competency for the mastery of the dominant discourses, conventions, and skills needed to successful growth in a specific discipline.

This study contends that studies that completely concentrate on commercial English proficiency in South Africa are far and wide or simply non-existent. This study, in focusing solely on commercial English proficiency of the $4^{\text {th }}$ year level and PGCE student teachers of Limpopo University fills a critical gap.

\section{Method}

A mixed method approach, in which both quantitative and qualitative data was collected and analysed, was used in this study. The study focused on assessing the level of commercial English proficiency as well as investigating the causes of the low levels of the commercial language proficiency among BEd $4^{\text {th }}$ year and PGCE commercial major students.

\subsection{Measuring Instrument}

The data collection in this study was done using a commercial language proficiency test that was developed by adapting English proficiency tests available in literature. Items which test commercial English comprehension and commercial language vocabulary in both written and oral conversations formed the commercial English proficiency test. The questions included in the test were also developed in consultation with subject matter experts, as well as considering the exit level competencies of the commercial subjects' modules. This was done to ensure that the questions asked were at the appropriate level of difficulty. The researchers complied with all the ethical considerations. . The participants were informed of their voluntary participation, assured of confidentiality of the information they provided and that all cultural and religious differences were respected. Furthermore, the participants were informed of their rights to withdraw from the study at any time.

\subsection{Sample and Sampling procedure}

From a population of $60 \mathrm{BEd} 4^{\text {th }}$ year student teachers and 122 PGCE students, the Raosoft sample size calculator yielded a minimum recommended sample size of 124 respondents. However, to caterfor non-response, the test was administered to 150 respondents. The minimum recommended sample size was calculated using a margin of error of $5 \%$, $95 \%$ confidence levels and a 50\% response distribution.

\subsection{Data Analysis}

The data collected through the proficiency test was analysed using quantitative methods in SPSS. Descriptive statistics were calculated and correlation tests were conducted to assess the direction and strength of the relationships between the variables. In order to counter the probability of a Type 1 error, a significant value was set at a $95 \%$ confidence interval level $(p \leq 0.05)$. For the purposes of this study, $r$ values greater than 0.3 were considered to be practically significant. Tests that were conducted included means, t-tests and correlations. Cronbach's Alpha coefficients were used to assess the internal consistency of the measuring instrument. In line with Cooper and Schindler's (2008) a Cronbach's alpha coefficient above 0.70 was considered as indicating the reliability of the measuring instrument.

\section{Research Findings}

\subsection{Response rate}

A hundred and fifty (150) proficiency test papers were administered to a group of students consisting B ED and PGCE students and hundred and six (106) test papers were returned. Theresponse rate was $70.7 \%$ and this was considered sufficient.

\subsection{Normality of data}

According to Coakes (2005) the normality of the data can be determined by using the Kolmogorov-Smirnov test (if the 
sample size is above 100) and the Shapiro-Wilks test (if the sample size is below 100). If the significance level is greater than 0.05 using either of the two tests, then normality isconfirmed. This study used the Kolmogorov-Smirnov test to determine the normality of the data because the sample size was more than 100 . The significance of the KolmogorovSmirnov test was greater than 0.05 in all the tests. This implies that non-parametric tests can be applied in analysing this data.

\subsection{Reliability of the research instruments}

The Cronbach's alpha coefficient was used for assessing the internal consistency of the commercial English proficiency test and coefficients greater than or equal to 0.70 (Cooper and Schindler, 2008) were considered high enough to denote adequate consistency and reliability. Based on the Cronbach's apha coefficient the commercial English proficiency test used in this study achieved a coefficient of 0.81 , therefore the internal consistency and reliability of this instrument can beinferred.

Table 1: Reliability of the test

\begin{tabular}{|l|c|}
\hline & $a$ coefficient \\
\hline General commercial expressions & 0.76 \\
\hline Vocabulary & 0.83 \\
\hline Comprehension & 0.74 \\
\hline Error correction & 0.71 \\
\hline \multicolumn{1}{|c|}{ Overall } & $\mathbf{0 . 8 1}$ \\
\hline
\end{tabular}

\subsection{Summary of descriptive statistics and participants' details}

\subsubsection{Age}

The majority of respondents (53.8\%) in this test were in the age group 21-25 years old, followed by the age group 26-40 (37.7\%). Respondents in the age group 31-35 years old consisted of $7.5 \%$ of the sample and only $0.9 \%$ of the sample was 36 years old and above.

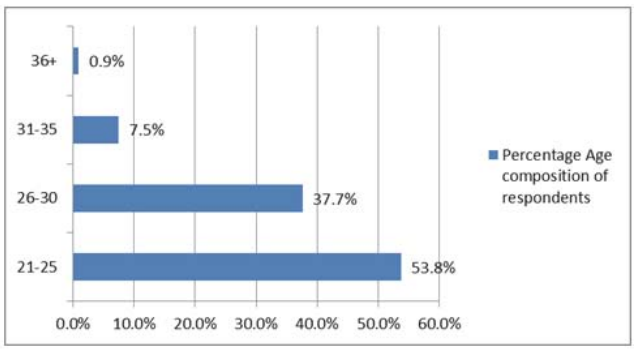

Fig1: Percentage Age Composition of respondents

\subsubsection{Gender Composition}

The majority of the respondents in this study were female (73.6\%) and male consisted of $26.4 \%$.

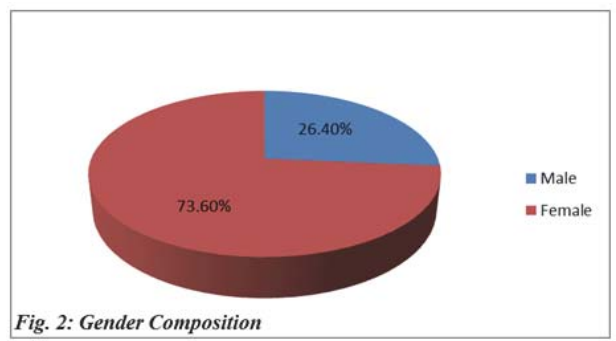




\subsubsection{Programme of study}

Almost fifty three percent $(52.8 \%)$ of the respondents were in their PGCE programme of study and $47.2 \%$ of the respondents were from the B ED programme.

Table 2: Programme of Study

\begin{tabular}{|c|c|c|c|c|}
\hline & Frequency & Percent & Valid Percent & Cumulative Percent \\
\hline B ED & 50 & 47.2 & 47.2 & 47.2 \\
\hline PGCE & 56 & 52.8 & 52.8 & 100.0 \\
\hline Total & 106 & 100.0 & 100.0 & \\
\hline
\end{tabular}

\subsection{Proficiency test results}

\subsubsection{Overall Mean scores}

The first objective of this study was to assess the level of commercial English proficiency of the B ED and PGCE students. The mean test score among the PGCE students was $46.9 \%$ whereas the mean test score for B ED students was $36.03 \%$. This is an indication that PGCE students, on average performed better than B ED students in this commercial English proficiency test. A possible explanation could be that the PGCE students were exposed to the commercial English language throughout their first degree programmes in commerce. This explanation is confirmed by Cummins' (2008) findings that the exposure to a language for an extended period of time has a positive influence on the mastery of the language. However, the mean scores of both groups where below the acceptable level of $50 \%$ which is an indication that the level of commercial English proficiency among the both B ED and PGCE is generally low.

\subsubsection{Differences in Commercial language Proficiency}

The second objective of this study was to determine whether there are significant differences between B ED students and PGCE students in respect of their level of commercial language proficiency. T-tests were conducted to determine if there are significant differences in performance in the four sections of the commercial language proficiency test. As shown in table 3 , the results revealed statistically significant differences in the performance of the two groups in general commercial expressions ( $\mathrm{t}=2.329$, sig.0.022); Vocabulary ( $\mathrm{t}=2.287$, sig. 0.025$)$ and Error correction ( $\mathrm{t}=-2.608$, sig. 0.009). No statistically significant difference in comprehension between the two groups ( $t=1.530$, sig.0.129) was found, this is an indication that the level of comprehension of commercial English among the B ED and PGCE students is almost the same.

Table 3: Mean Scores and t-test results

\begin{tabular}{|c|c|c|c|c|c|c|}
\hline \multirow[t]{2}{*}{ Variable } & \multicolumn{2}{|c|}{ B ED students } & \multicolumn{2}{|c|}{ PGCE students } & \multicolumn{2}{|c|}{ t-test } \\
\hline & Mean & SD & Mean & $\mathrm{SD}$ & $t$ & Sig. \\
\hline General Commercial expressions & 46.3 & 8.6 & 62.1 & 4.6 & 2.329 & .022 \\
\hline Vocabulary & 57.8 & 4.3 & 47.2 & 11.2 & 2.287 & .025 \\
\hline Comprehension & 34.6 & 11.6 & 33.4 & 9.7 & 1.530 & .129 \\
\hline Error correction & 38.9 & 2.4 & 41.4 & 6.3 & -2.608 & .009 \\
\hline Overall & 36.03 & & 46.93 & & & \\
\hline
\end{tabular}

${ }^{*}$ Sig. $p<0.05$

By analysing the means at each section, the results shows that on average PGCE scored higher in General commercial expressions (62.1\%) and in Error correction (41.4) whereas B ED students scored high in the Vocabulary (57.8\%) and comprehension (34.6\%).

\subsubsection{Correlations between general commercial expression, vocabulary, comprehension and Error correction}

In order to establish the relationship between commercial English expression, vocabulary, comprehension and error correction, a Spearman's Ranks correlation analysis was done. Statically significant positive correlations were found 
between general commercial English expressions and Comprehension ( $r=0.653 ; p=0.02)$, between comprehension and Vocabulary $(r=0.668, p=0.005)$ as well as between Error correction and Vocabulary $(r=0.458, p=0.008)$. Although a positive correlation was found between error correction and vocabulary, such a correlation is very weak $(r=0.485)$. It was expected that commercial English expressions would correlate positively with comprehension. Such a positive correlation between commercial English expression and comprehension may be explained by the Lahey and Bloom's (1994) limited capacity system. Lahey and Bloom (1994:361) pointed out that "holding mental models in mind uses a portion of a limited supply of cognitive resources". This is mainly because an ability to express one-self using the subject specific terms may translate into the ability to comprehend the terms when expressed in another context.

Table 4: Correlations between general commercial expression, vocabulary, comprehension and Error correction

\begin{tabular}{|c|c|c|c|c|c|c|}
\hline & $\begin{array}{l}\text { Commercial English } \\
\text { expressions }\end{array}$ & Vocabulary & Comprehension & $\begin{array}{c}\text { Error } \\
\text { correction }\end{array}$ \\
\hline \multirow{4}{*}{$\begin{array}{c}\text { Spearman's } \\
\text { rho }\end{array}$} & $\begin{array}{l}\text { Commercial English } \\
\text { expressions }\end{array}$ & $\begin{array}{c}\text { Correlation Coefficient } \\
\text { Sig. (2-tailed) } \\
\text { N }\end{array}$ & $\begin{array}{c}1.000 \\
106\end{array}$ & $\begin{array}{l}-.081 \\
.408 \\
106\end{array}$ & $\begin{array}{l}.653 \\
.002 \\
106\end{array}$ & $\begin{array}{l}-.002 \\
.981 \\
106\end{array}$ \\
\hline & Vocabulary & $\begin{array}{c}\text { Correlation Coefficient } \\
\text { Sig. (2-tailed) } \\
\text { N }\end{array}$ & $\begin{array}{l}-.081 \\
.408 \\
106\end{array}$ & $\begin{array}{c}1.000 \\
\dot{1} \\
106\end{array}$ & $\begin{array}{l}.668 \\
.005 \\
106\end{array}$ & $\begin{array}{l}.458 \\
.008 \\
106\end{array}$ \\
\hline & Comprehension & $\begin{array}{c}\text { Correlation Coefficient } \\
\text { Sig. (2-tailed) } \\
\text { N }\end{array}$ & $\begin{array}{l}.653 \\
.082 \\
106\end{array}$ & $\begin{array}{l}.668 \\
.005 \\
106 \\
\end{array}$ & $\begin{array}{c}1.000 \\
. \\
106\end{array}$ & $\begin{array}{l}-.043 \\
.658 \\
106 \\
\end{array}$ \\
\hline & Error correction & $\begin{array}{c}\text { Correlation Coefficient } \\
\text { Sig. (2-tailed) } \\
\text { N }\end{array}$ & $\begin{array}{l}-.002 \\
.981 \\
106\end{array}$ & $\begin{array}{l}.458 \\
.008 \\
106\end{array}$ & $\begin{array}{l}-.043 \\
.658 \\
106\end{array}$ & 1.000 \\
\hline
\end{tabular}

No significant correlation was found between commercial English expression and vocabulary $(r=-0.081, p=0.408)$. This finding is inconsistent with literature such as Xia (2010:10) who argued that, "... vocabulary is of great significance in expressing thoughts and ideas in interaction activities".

\section{Discussion}

The results of this study reveal low commercial language proficiency among the respondents of this study. These findings are consistent with other studies (Possel and Zeller, 2010; Webb and Kembo-Sure, 2000) on language proficiency (however, not specific to commercial language) among black African participants. Therefore, from a practical perspective an integrated approach to commercial language development among African students can go a long way in enabling commercial subjects' educators to deliver the subjects to their learners eloquently and fluently. Such delivery is of great value in reinforcing the links between language teaching and the general aims of the commercial subject teaching which are to develop citizens who are able to make meaningful contributions to socio-economic growth, development, their personal growth and adding value to their societies.

Based on the findings that the commercial language proficiency of both B ED and PGCE is generally low among the commerce students, a programme tailored towards improving commercial language proficiency could be developed and introduced, with a particular emphasis on the idea that if students who are expected to be specialists in the field are to perform efficiently, their subject specific language proficiency must be up to standard.

In addition, student teachers could be encouraged to have conversations and interactions (Lightbown and Spada, 2002) often using the commercial expression such that unconsciously, the commercial language grows in them and at the same time emphasising the use of the commercial language by the lecturer in their teaching of these students. This recommendation is informed by Krashen's (1987) input hypothesis. Krashen, (1987:56) pointed out that:

"... (Language) acquisition arises as the result of processes of creative construction by which the learner internalizes the rules of the second language subconsciously; it takes place naturally and is not amenable to instruction. In contrast, learning is a conscious process that results from formal study and which can be influenced."

Although significant differences were found between the commercial language proficiency of B ED and PGCE students, the level of proficiency of both groups is, by generally acceptable standards very low. This by implication means 
that both groups require subject specific, i.e. commercial language teaching, before they could go out to teach their respective subjects.

Furthermore, the findings that proficiency in general commercial expression is positively correlated to comprehensions is of great implications to commercial subjects' teachers. A lot of texts in the commerce field are presented using technical terms that are unique to the field and sometimes to a particular subject. Therefore if the prospective commercial subjects' teacher is to be successful in their teaching they need to be proficient in their use of commercial expressions in their teaching and transfer such skills and knowledge to their learners.

Furthermore the environment in which teaching and learning takes place play a major role in the development of subject specific English proficiency. For instance, in an environment where the $4^{\text {th }}$ level and the PGCE student teachers have been attending in an overcrowded and under-resourced lecture halls, with University lecturers themselves not being proficient in commercial subject specific terminology, it is expected to have student teachers reflecting and mirroring that schooling environment so aptly. Therefore endeavours to improve the environment in which teaching and learning takes place at the university are imminent.

\section{Conclusions}

The aim of this study was to contribute to the endeavours to improve teaching and learning in commercial subjects in South African schools through assessing commercial English proficiency among exit level student teachers. An assessment of the commercial language proficiency revealed that there are generally low levels of commercial English proficiency among the B ED and PGCE students majoring in commercial subjects. This implies that both B ED and PGCE students majoring in commerce subjects require training in the subject specific language. Further studies exploring this issue, using varied methodologies are recommended to advance this discourse on attempts to address lack of subject specific language proficiency in the fields of commerce and beyond.

In the words of Nelson Mandela, former and first President of the democratic South Africa:

"Education is the great engine of personal development. It is through education that the daughter of a peasant can become a doctor, that the son of a mineworker can become the head of the mine, that a child of farm workers can become the president of a great nation. It is what we make out of what we have, not what we are given, that separates one person from another."

However,

"The power of education extends beyond the development of skills we need for economic success. It can contribute to nation-building and reconciliation"

On that note, it is the mastery and communication in a subject specific language that distinguishes a specialist in one field from another. Hence success in the commerce field is dependent upon the ability to speak, live and act the language of the field.

\section{References}

Alexander, N. 2000. Key issues in language policy for Southern Africa. Paper presented at the conference: Language and development in Southern Africa. Making the right choices. Okahandja: National Institute of Educational Development (NIED).

Barkhuizen, G.P. \& Gough, D. 1996. Language curriculum development in South Africa: What place for English? TESOL Quarterly, 30(3), 453-471.

Brock-Utne, B. and Holmarsdottir, H.B. 2004. Language policies and practices in Tanzania and South Africa: problems and challenges. International Journal of Educational Development 24:67-83.

Christie, F. and Macken-Horarik, M. 2007. 'Building verticality in subject English'. In Christie, F. and Martin, J.R. (eds.) Language, Knowledge and Pedagogy. Functional Linguistic and Sociological Perspectives. London and New York: Continuum, pp. 156-83.

Coakes, S.J. 2005. SPSS Version 12.0 for windows Analysis without Anguish. Sydney: John Wiley \& Sons Australia Limited.

Cooper, D. R. \& Schindler, P. S. 2008. Business Research Methods, 10th edition. Boston: McGraw-Hill Irwin.

Cummins, J. 2008. BICS and CALP: Empirical and Theoretical Status of the Distinction. In B. Street, and N. Hornberger, Encyclopedia of Language and Education: (Vol. 2, pp. 71 - 83). New York: Springer.

Dang, T.N.Y and Webb, S. 2014. The lexical profile of academic spoken English. English for Specific Purposes 33: 66-76.

Finlayson, R. and Mbulungeni, M. 2002. The Intellectualisation of the Indigenous Languages of South Africa: Challenges and Prospects. Current Issues in Language Planning 3(1):40-61.

Helmer, K.A. 2013. Critical English for academic purposes: Building on learner, teacher, and program strengths. Journal of English for 
Academic Purposes 12: 273-287.

Heugh, K., 2000. The Case Against Bilingual and Multilingual Education in South Africa, PRAESA Occasional Papers No. 6. PRAESA, Cape Town, South Africa.

Hove, M.L. 2012. Hyphenated validity: Comparability of assessment protocols in English language between two examination boards. South African Journal of Education, 9(1):1 10.

Krashen, S. D. 1987. Principles and Practice in Second-Language Acquisition. Oxford: Pergamon Press Ltd.

Lahey, M. \& Bloom, L. 1994. Variability and Language Learning Disabilities. In G. P. Wallach \&K. G. Butler (Eds.), Language Learning Disabilities in School-Age Children and Adolescents. New York: Merrill.

Lightbown, P.M. and Spada, N. 2002. How Languages Are Learned. Shanghai: Shanghai Foreign Language Education Press.

Luckett, K. 1995. National Additive Bilingualism: Towards a Language Plan for South African Education. In Heugh K, Siegruhn A \& Pluddemann P (eds) Multilingual Education for South Africa. Isando: Heinemann Publishers Ltd. pp. 73-79.

MacDonald, C.A. 1990. Crossing the Threshold into Standard Three in Black Education: the Consolidated Main Report of the Threshold Project. Pretoria: Human Sciences Research Council.

Nkabinde, Z.P. 1997. An Analysis of Educational Challenges in the New South Africa. Lanham, Md: University Press of America.

Posel, D. and Casale, D. 2011. Language proficiency and language policy in South Africa: findings from new data. International Journal of Educational Development 31(5): 443-451.

Pradhan, A. 2013. English for Specific Purposes: Research Trends, Issues and Controversies. English for Specific Purposes World, 14(40): 1-13.

Probyn, M. 2006. Language and Learning Science in South Africa. Language and Education 20(5):391-414.

Valipouri, L. and Nassaji, H. 2013. A corpus-based study of academic vocabulary in chemistry research articles. Journal of English for Academic Purposes 12(4): 248-263.

Van Der Walt, C, Evans, R. and Kilfoil, W.R. 2009. Learn 2 teach. English language teaching in a multilingual context. 4th revised edition. Pretoria. J.L.van Schaik Publishers.

Webb, V.N. and Kembo-Sure J (eds). 2000. African Voices: An Introduction to the Languages and Linguistics of Africa. Oxford: Oxford University Press.

Xia, J. 2010. Communicative Language Teaching in Vocabulary Teaching and Learning in a Swedish Comprehensive Class. [online] available at $h$ ttp://hkr.diva-portal.org/smash/get/diva2:328283/FULLTEXT01.pdf Accessed 03 July 2013. 